\title{
The Effectiveness of Using the Application of Coverage Management System (SIMPAN) at the Madya Tax Office Bekasi, West Java, Indonesia
}

\author{
Novianita Rulandari ${ }^{1}$, Setya Haryati ${ }^{2}$, Victor Van Kommer ${ }^{3}$, \\ Dwi Agustina $^{4}$, Diana Prihandini ${ }^{5}$ \\ 1,2,4,5Institut Ilmu Sosial dan Manajemen STIAMI, Indonesia \\ ${ }^{3}$ The International Bureau of Fiscal Documentation (IBFD), Netherlands \\ Correspondent: novianitarulandari@gmail.com ${ }^{1}$.
}

$\begin{array}{ll}\text { Received } & \text { : August 26, } 2021 \\ \text { Accepted } & \text { : January 15, } 2022 \\ \text { Published } & \text { : January 31, } 2022\end{array}$

Citation: Rulandari, N., Haryati, S., Kommer, V, V., Agustina, D., Prihandini, D. (2022). The Effectiveness of Using the Application of Coverage Management System (SIMPAN) at the Madya Tax Office Bekasi, West Java, Indonesia. Ilomata International Journal of Tax and Accounting, 3(1), 78-90. https://doi.org/10.52728/ijtc.v4i1.428

\begin{abstract}
The Archives Management System (SIMPAN) application is a breakthrough application innovation developed by the Bekasi Madya Tax Office to improve the performance of its employees in the context of monitoring and deepening tax revenue by improving the management and administration of taxpayer files and supervision of paying SPT (SPT) effectively and efficiently. The purpose of this study was to analyze the level of effectiveness of using the SIMPAN application. This study uses a qualitative descriptive method with data collection through observation, interviews, and documentation. The theory of effectiveness according to Campbell is used as a reference in this study. The results of the study indicate that the application of the SIMPAN application has been effectively carried out at the Bekasi Madya Tax Office.
\end{abstract}

Keywords: effectiveness, SIMPAN application, service, supervision

This is an open access article under the CC-BY 4.0 license.

\section{INTRODUCTION}

Currently, taxation is the largest contributor to Indonesia's state revenue. In 2019, the figure generated from tax revenues was 1,332.66 trillion rupiahs, although the tax ratio this year is still at $10.7 \%$. Meanwhile, in 2020, the figure generated from tax revenue is 1,072.1 trillion rupiahs. From the data on the realization of the 2020 APBN, the realization of tax revenues was recorded at Rp. 1,072.1 trillion or a $19.6 \%$ contraction compared to the realization in 2019. This realization was $89.4 \%$ of the APBN target from Perpres 72 or there was a shortfall of around Rp. 126.7 trillion (Kementerian Keuangan, 2021; Masdi, 2021).

Since 2020 the whole world has been faced with the challenge of adversity, especially in the economic sector due to the COVID-19 pandemic where this has an impact on the economy both macro and micro (UNICEF, 2021). Indonesia is one of the countries affected by the Covid-19 pandemic with the largest number of people infected with COVID-19 in the world (Haryanto, 2020; Shalihah, 2020) 

The Effectiveness of Using the Application of Coverage Management System (SIMPAN) at the
Madya Tax Office Bekasi, West Java, Indonesia

Rulandari, Haryati, Kommer, Agustina, Prihandini

The movement restriction policies issued by the Central Government and Regional Governments to reduce the spread of this epidemic will certainly have a direct impact on the national economy (Muhyiddin \& Nugroho, 2020). Many entrepreneurs stop their business operations because they are unable to pay for employees and office operations. National economic growth grew minus 1.1 percent, the Minister of Finance of the Republic of Indonesia at the time said that the Indonesian economy had entered the recession stage (Rahmah, 2020).

Even though the government issued a policy of limiting this activity, the economy in Indonesia, both at the center and at the regional level, must continue (Górska et al., 2021; Wiryawan, 2020). And to finance economic activities, the government needs funds whose largest contribution is still based on tax revenues which nationally account for about $75 \%$ of total state revenues (Anggraini et al., 2021). Meanwhile, the tax is a mandatory contribution from the community to the state based on the law where the community does not get a direct contra-performance and this levy is used to finance state development to achieve public welfare (Aditya, 2021; Harjo, 2019).

In addition to public awareness of the fulfillment of their tax obligations, among others, the lack of willingness to pay taxes, which is partly because people do not know the concrete form of rewards from the money spent to pay taxes (Latofah \& Harjo, 2020). One form of supporting the achievement of tax revenue targets is by utilizing information technology in the form of computerized applications where information systems are built, developed and used to carry out service processes to the community through an integrated system.targets (Hajawiyah et al., 2021; Pendit et al, 2021). The utilization of information technology carried out by the tax office is no longer a luxury but has become a necessity (Bai et al., 2021; Syafitri, 2018). The efficiency, effectiveness, and productivity of an public and private organizations company work either at the individual, group level, or at the organization or company level as a whole can be improved by the use of these application technologies (Wulandari, 2021).

In improving services for its taxpayers, the Bekasi Madya Tax Service Office, West Java, Indonesia created an internal computerized application that connects between Divisions and Sections in the office which is named the Archives Management System Application (SIMPAN). Through the SIMPAN application, it is expected to be able to increase speed and accuracy in providing services to the public, especially taxpayers, and internally it is also hoped that this application can improve employee performance to support DGT to used to carry out service processes to the community through an integrated system targets and ultimately foster public confidence, in the end it fosters public trust, especially better management of taxpayer administration. management

Some phenomena that occur in connection with this SIMPAN application are:

1. The DGT's internal public service applications are still separate from each other applications are still separate from one another.

2. In terms of administration of Taxpayer documents, there is no standardization of filing, the old process of copying borrowing Taxpayer documents, requires good resources in terms of filing, the unavailability of a Taxpayer document filing system, and Taxpayer document borrowing that is not by procedures. 
The Effectiveness of Using the Application of Coverage Management System (SIMPAN) at the Madya Tax Office Bekasi, West Java, Indonesia

Rulandari, Haryati, Kommer, Agustina, Prihandini

3. In the completion of the overpaid SPT (SPTLB), a partial application, there is a risk of delay in the completion of the SPTLB examination, causing the risk of interest compensation and sanctions to tax officials.

4. There is inefficiency in the use of paper that should have been done digitally.

Because sophisticated information technology is the key to the successful implementation of tax policy and is expected to be able to improve employee performance in the agency's efforts to achieve the goal of achieving tax revenue targets, in line with this the authors designed the objectives of this study as follows:

1. To analyze the effectiveness of the application of the Archives Management System Application (SIMPAN) in improving the performance of the Bekasi Madya Tax Office employees.

2. To analyze the obstacles to the application of the Archives Management System Application (SIMPAN) in improving the performance of the Bekasi Madya Tax Office employees.

3. To analyze efforts to overcome obstacles to the application of the Archives Management System Application (SIMPAN) in improving the performance of the Bekasi Madya Tax Office employees.

Several theories related to this research include the notion of effectiveness. According to Mardiasmo, "Effectiveness is a measure of the success or failure of achieving goals an organization achieves its goals. When an organization achieves its goal then the organization has been running effectively. Effectiveness indicators describe reaching consequences and impacts (outcomes) of the program's outputs in achieving program objectives. The bigger the contribution the resulting output towards the achievement of the specified goals or objectives, the more effective the work process an organizational unit" (Mardiasmo, 2016)

According to Campbell, there are four dimensions those affect the level of effectiveness of an activity, namely 1 . The success of the program has two entities, namely the program in the SIMPAN application and improving employee performance. 2. The success of the target, focusing on the output to be achieved, has two entities, namely so that the SIMPAN application can be used by all employees and the function of making this SIMPAN application for employees of KPP Madya Bekasi. 3. Satisfaction with the program, which has two entities, namely employee satisfaction at KPP Madya Bekasi as users of the SIMPAN application and the effectiveness of the SIMPAN application in improving employee performance at KPP Madya Bekasi, and the fourth dimension, namely the achievement of overall goals by looking at the extent of the target from in terms of quality, quantity and time achieved by the institution, namely the achievement of predetermined targets and future expectations with the SIMPAN application. The four dimensions of Campbell's theory will be operationalized in this study (Shabrina, 2014).

The Filing Management System (SIMPAN) application is a breakthrough application innovation developed by KPP Madya Bekasi to improve the performance of Bekasi Madya Tax Office employees in the context of monitoring and extracting tax revenues by improving the management and administration of Taxpayer files, monitoring SPT Overpaid, reporting 
The Effectiveness of Using the Application of Coverage Management System (SIMPAN) at the Madya Tax Office Bekasi, West Java, Indonesia

Rulandari, Haryati, Kommer, Agustina, Prihandini

compliance Taxpayers in submitting SPT effectively and efficiently. Applications are also built as a means of storing, searching, monitoring, and supervising digital legal documents/products, Taxpayer applications as well as other data and documents to support a reliable, easy, and efficient office administration system trusted (Irkham et al., 2021).

Related to the administration and supervision of taxpayer compliance with the following principles:

a. To support the modernization of Information Technology of the Directorate General of Taxes, the system that is built must improve the performance of all sections with the application standards of the Head Office of the Directorate General of Taxes;

To support the modernization of Information Technology Directorate General of Taxes, the system built must be able to support each other with standard Head Office applications Directorate General of Taxation;

b. This internal access security system is integrated with the Information System of the Directorate General of Taxes which is used externally, in the sense that it can be accessed by taxpayers

The security system for access to the system is integrated with the Information System of the Directorate General of Taxes;

c. The system that is built does not duplicate the existing system Head Office of the Directorate General of Taxes and is an invention new, original.

The SIMPAN application which is an internal application at the Bekasi Madya Tax Office consists of menus related to administration and supervision, namely:

The SIMPAN application consists of related menus administration and supervision, namely:

1) Administration

1. The e-Office application for correspondence is for recording incoming and outgoing mail faster and saving incoming mail documents and documents digital out-of-office letters;

2. Taxpayer Library application in the form of document digitization Taxpayers (digital archiving), make it easier to search for taxpayer documents, make it easier search for legal products that have been published, support employee performance related to the use of data/documents both internal data in the DGT and data borrowed from Taxpayer for tax audit purposes;

3. Application of e-Reporting in the form of Mentoring Inspection. To make a mentoring report easier and faster, monitoring implementation Tax Auditor Functional field inspection;

4. Postal Delivery/Delivery Applications, namely for creating a mail delivery register by post more easy and fast, and monitoring of delivery decisions and other letters using the Post in the Section Service;

2) Supervision

1. Overpaid SPT Dashboard Application, as innovation supervision of the Maturity of Annual Report of Overpaid Taxes (SPT LB) with integrated data from Directorate Information System General Tax (SIDJP) and Report Application Tax Audit (ALPP); 
The Effectiveness of Using the Application of Coverage Management System (SIMPAN) at the Madya Tax Office Bekasi, West Java, Indonesia

Rulandari, Haryati, Kommer, Agustina, Prihandini

2. SPT Reporting Compliance Dashboard Application for monitoring the submission of the Taxpayer's Annual SPT and make it easier for employees, especially Account Representative to do supervision of taxpayer compliance level;

3. Tax Invoice Confirmation Application to answer confirmation of tax invoices/proof of deduction on time, and follow-up tracking of invoice confirmation answers withholding tax/proof;

4. Application for Free Certificate Application, Application for Objection, Application for Extension Submission of SPT, Application for Overbooking, and Warrant for Paying Excess Tax (SPMKP) namely to monitor the application of the Taxpayer and tracking and viewing application documents until with legal products published easily because already digitized;

5. The Service Satisfaction Dashboard application is the monitoring of taxpayer satisfaction with services provided by the Integrated Service Center officer (TPT) and as material for evaluating the performance of TPT officers;

6. Monitoring Application for Issuance of Tax Assessment Letters to monitor the issuance of Tax Assessment Letters and other legal products so that they are not past due.

By using the theoretical approach mentioned above, in completing the work, especially the maturity of tax refunds, taxpayer compliance in submitting the Annual Tax Report (SPT Report) can be achieved, so that the performance of the Bekasi Madya Tax Office employees can increase. In addition, the management and administration of taxpayer files are digital, so the performance of Bekasi Madya Tax Office employees in completing work is expected to increase.

The factors that influence effectiveness according to Campbell are associated with the implementation of this SIMPAN application are 1. The success of the program has two entities, namely the program in the SIMPAN application and improving employee performance. 2 . The success of the target, focusing on the output to be achieved, has two entities, namely so that the SIMPAN application can be used by all employees and the function of making this SIMPAN application for employees of KPP Madya Bekasi. 3. Satisfaction with the program, which has two entities, namely employee satisfaction at KPP Madya Bekasi as users of the SIMPAN application and the effectiveness of the SIMPAN application in improving employee performance at KPP Madya Bekasi, and the fourth dimension, namely the achievement of overall goals by looking at the extent of the target from in terms of quality, quantity and time achieved by the institution, namely the achievement of predetermined targets and future expectations with the SIMPAN application. Campbell theory will be appointed as a reference in this study, by presenting the research conceptual model as follows: 
The Effectiveness of Using the Application of Coverage Management System (SIMPAN) at the Madya Tax Office Bekasi, West Java, Indonesia

Rulandari, Haryati, Kommer, Agustina, Prihandini

Figure 1

Conceptual Model

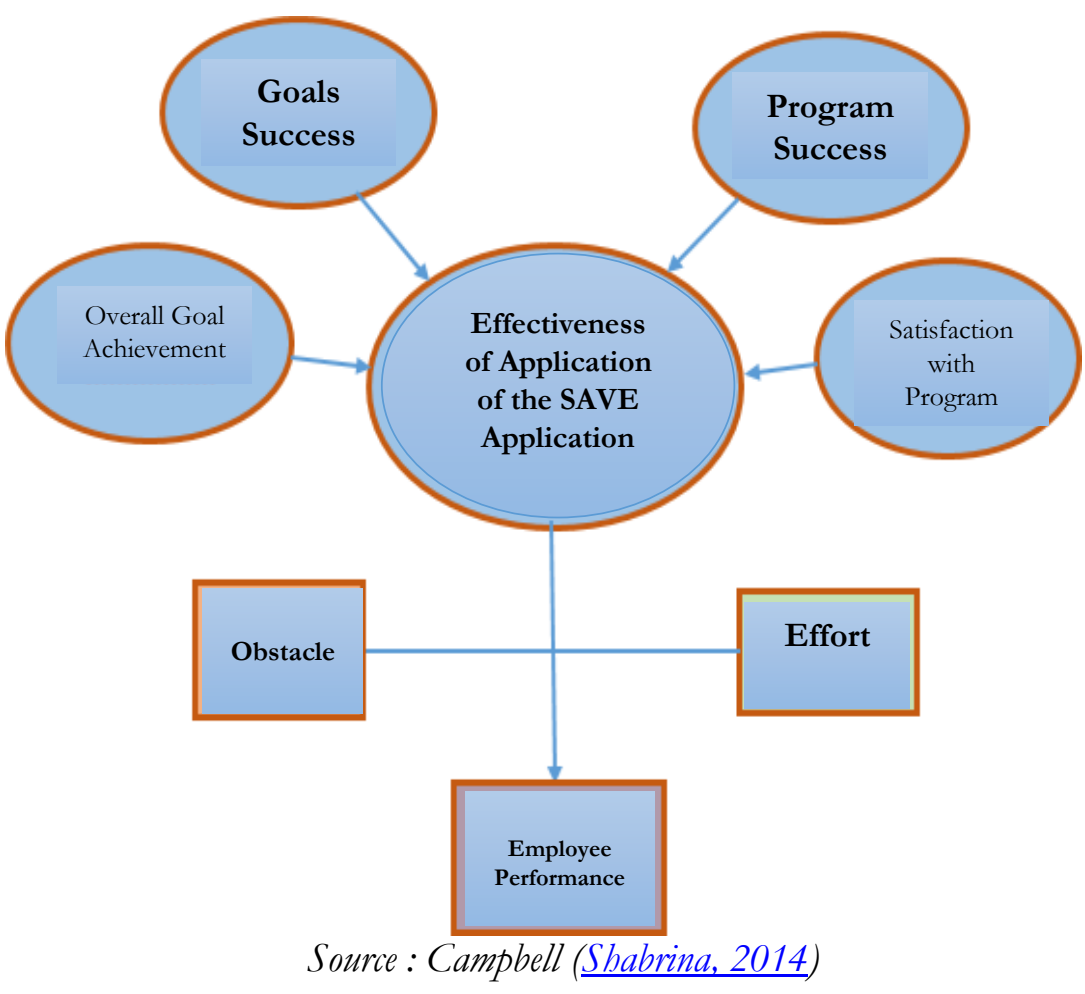

Several previous studies that were also used as references in the preparation of this scientific paper include :

1. Hertiwi, who researched about Application System Information Management For Productivity Boost Work On Service Communication And informatics (Diskominfo) district North Lombok 2020 (Journal of Science Administration Public, Vol.9 No.1, 2020). Hertiwi's research results show that the implementation of the Management Information System at the Communication and Information Office of North Lombok Regency has been effective. Judging from the use of the website in disseminating information to the public, it can be faster, more economical, and cheaper, so that it can reduce the Department's budget expenditure. There are two supporting factors for the implementation of SIM, namely internal factors and external factors, while the inhibiting factors in implementing this SIM are lack of budget, lack of aspirations from the community, and lack of expert resources. Then efforts to increase employee work productivity at the Communication and Information Office of North Lombok Regency, are still less effective, several obstacles were found, namely the lack of employee motivation, employees lack expertise, salaries that are not appropriate/low and office facilities are not adequate ( $\underline{\text { Hertiwi, 2020) }}$

2. Research conducted by Putri Dwi February (2019), entitled Effectiveness of Regional Management Information System Application Application (SIMDA) Finance at the Tanah Datar Regency DPRD Secretariat Office. This study focuses on how effective the SIMDA application is in Finance at the Tanah Datar Regency DPRD Secretariat to help the financial management process produce financial reports accurately, in a quality, and 
The Effectiveness of Using the Application of Coverage Management System (SIMPAN) at the Madya Tax Office Bekasi, West Java, Indonesia

Rulandari, Haryati, Kommer, Agustina, Prihandini

timely. Measurement indicator effectiveness used in this study, among others, the success of the program, target success, satisfaction with the program, and overall goal achievement. The results of this study show that the financial SIMDA application has been successfully implemented at the secretariat since 2009. This application is very effective because makes the financial management process easier and reports can be generated quickly and accurately. But the effectiveness of its implementation in the secretariat of the Tanah Datar Regency DPRD is still not maximum because there are still several inhibiting factors such as there are still many employees who cannot operate SIMDA so some goals have not been achieved to the maximum, yet holding special training on the use of SIMDA for employees, still lack of hardware availability as well as network disruption that often hinder the process of using SIMDA Finance (Febria et al., 2018).

3. Previous study shows the effectiveness of the implementation of the personnel management information system at the regional staffing and education and training agency which is looking at the four criteria, namely adaptation, integration, and undeveloped production effectiveness. This is evidenced by observations and interviews that have been done, the adaptation and motivation criteria have not been effective because at the agency the number of operators who are able to operate applications with available technology is still very limited, and provision of training for non-routine data processing staff and has not been effective in providing technological facilities and infrastructure information, in this case, is still lacking a computer for processing data (Diani, 2017).

4. The next previous research shows that integrating information technology into business processes, for example, Enterprise Resource Planning system (Enterprise Resource Planning), Supply Chain Management system (Supply Chain Management), and Inventory management, ignoring modernization human management systems such as performance management, can be a misguided investment (Chen et al., 2019). This is a form of implementation of information technology in many public institutions. Regardless of how good the technology was and how big is the investment, if the people working on the system Information technology is inefficient, a business cannot be productively (Tray et al., 2020). Therefore, the efficiency of information technology systems can only deliver results if there is a high level of efficiency from people who use the system. Institutions that have implemented and automated its performance system has benefited from the system in terms of cost savings, speed service delivery, productivity, and quality of service offered. To ensure the impact of the performance management system supported by information technology within the organization; researchers investigate the use of performance management systems in Zambian public institutions and how the system impacts efficiency and productivity (Mapoma, 2017).

The similarity in several previous studies with this research is that they both examine management information systems, while the difference is in the theory used as a reference, place, and year of research. 


\section{METHOD}

A descriptive qualitative research approach will be used to analyze the problems in this study because the authors want to explore in detail and intensively the policies of the modern tax administration system to improve taxpayer compliance. In addition, another reason the author chooses a qualitative approach is the study of the literature in this study and the pattern of inductive research thinking. This research is not to test the truth of a theory, but to conclude what happened (Sugiyono, 2019).

The type of research used in this research is descriptive research which describes and explains in detail the phenomena or problems that exist in the status of human groups, objects, conditions, and systems of thought or events in the present. This type of research seeks to explain certain social phenomena (Creswell, 2017) .

The data collection techniques used were conducting observations, conducting interviews with several informants, and documenting some data that were considered important and relevant to this research. The data collection technique used is to make observations, conduct interviews with several informants who come from elements of the SIMPAN application users, namely employees of the Bekasi Madya Tax Office, Taxpayers as recipients of services from tax officials and academics, and documenting some data that is considered important and relevant to this research. This technique is by what was stated by Sugiyono that "Data Collection Methods are the methods used by researchers to collect data."

The data analysis technique is an activity that begins with collecting data, then choosing the validity of the data that has been collected, choosing a particular coding to be effective in conducting research, and drawing a decision to do research. In carrying out data analysis techniques, the authors use the techniques proposed by Miles \& Huberman, namely through the stages of data reduction, displaying data (with verbatim encoding), and concluding.

The data reduction stage is sorting and selecting the collected data, both data from interviews and data from documentation with the aim that the author will choose valid and relevant data to the research to be carried out, so not all the collected data will be used as research data. The next stage is to display the data in this case the author uses verbatim coding to facilitate data analysis and the last stage is to draw conclusions based on the analysis carried out.

In conducting interviews, the writer chose several informants with the criteria that the informants knew and understood about the problems to be analyzed, also the informants were needed to explore the information that became the basis and the theoretical design that was built. In determining informants in qualitative research, it is possible to use three methods, namely the purposive procedure (deliberate), the quota procedure, and the snowball procedure (Bungin, 2017). Purposive sampling is the author's choice in selecting informants. The selected informants represent 10 people from Bekasi Madya Tax Office, 2 taxpayers, and 1 person from academics. The informants from the Tax Office consist of the implementing level to the Section Head, the informants from the taxpayers consist of taxpayers who are directly related to the services and supervision carried out by the Bekasi Madya Tax Service Office, while the academic 

Madya Tax Office Bekasi, West Java, Indonesia

Rulandari, Haryati, Kommer, Agustina, Prihandini

element functions as a theoretical counterweight to statements resulting from interviews with informants who come from elements of the Tax Office and Taxpayers. In analyzing the data that was collected from interviews with informants, the authors used Verbatim coding solely to facilitate the data analysis process.

This study focuses on the effectiveness of using an internal application at the Bekasi Madya Tax Service Office, West Java Province, Indonesia, which is named the SIMPAN Application. The author uses Campbell's theory of effectiveness because the variables described in the theory are by the research theme that the author is examining. In researching a policy, the author needs to examine how the overall achievement is, how the target is successful, how the program is successful, and how satisfied the program has been implemented.

\section{RESULT AND DISCUSSION}

In conducting the analysis the author refers to the effectiveness theory Campbell which has 4 variables, namely success of the program, the success of the target, satisfaction with the program, and the achievement of overall goals by looking at the extent of the target from in terms of quality, quantity and time achieved by the institution with the discussion of the results as follows:

1. How is the effectiveness of the Archives Management System Application (SIMPAN) in improving the performance of Bekasi Madya Tax Office employees.

a. From the analysis that has been carried out using Verbatim coding about the success of the Archives Management System Application (SIMPAN) program in improving employee performance The Bekasi Madya Tax Service Office concluded that the SIMPAN application had been used by employees more than $80 \%$ of Bekasi Madya KPP employees who served in the field of service to taxpayers and the success of the SIMPAN application program was monitoring the Annual Report of Overpaid Taxes regarding Restitution, digitizing work, better document archiving, making it easier to find documents and monitoring progress. work faster, and a good tax application should be able to save time, effort, and space and reduce usage paper.

b. The conclusion that can be drawn from the Verbatim Analysis about the success of the Archives Management System Application (SIMPAN) application in improving the performance of the Bekasi Madya Tax Office employees is that this application has achieved the desired target because with this SIMPAN application the work of the implementers and supervisors become more effective and efficient, both in terms of time effectiveness at work as well as in spending on work implementation as well as better archive management, in terms of utilization of taxpayer document archives.

implementers and supervisors becomes more effective and efficient, management archives are better, in terms of the utilization of the taxpayer's document archives has been successful. The success of the SIMPAN application target is that there is systematic monitoring of the Annual Tax Report Overpayment regarding Restitution which reduces the occurrence of manual supervision errors, including miscalculations and errors in the timeliness of submitting information to taxpayers. The Annual Tax Report Overpayment regarding Restitution is not past due, makes it easier to supervise and monitor the date a work must be completed, archives that neatly makes it easy to search for data to 
The Effectiveness of Using the Application of Coverage Management System (SIMPAN) at the Madya Tax Office Bekasi, West Java, Indonesia

Rulandari, Haryati, Kommer, Agustina, Prihandini

complete work; so it is can support expected that the performance of employees, especially the State Civil Apparatus (ASN) at the Bekasi Madya Tax Office is more professional, independent and reliable.

c. From Verbatim's analysis of satisfaction with the Archives Management System Application (SIMPAN) program in improving the performance of Bekasi Madya Tax Office employees it was concluded that the SIMPAN application helped employees a lot in carrying out their work, the use of the SIMPAN application was appropriate and facilitated the work and was even able to improve the performance of KPP Madya Bekasi employees. The SIMPAN application is easy to access, the operation is easy, the display on the SIMPAN application is also very easy to understand so that employees can easily use the SIMPAN application. Applications that can help smooth service tasks if the application is easy to use, reducing manual work and human errors.

d. Analysis of research on the overall goal achievement of the Archives Management System Application (SIMPAN) in improving the performance of the Bekasi Madya Tax Service Office employees concluded that the use of the SIMPAN application was effective in improving employee performance because employees did not need to do the work manually. In terms of accuracy, the SIMPAN application is guaranteed to be accurate because the data presented is taken directly from the DGT Information System and other official applications from DGT. In terms of timeliness and relevance, it is good.

2. Verbatim's analysis of the obstacles to the application of the Archives Management System Application (SIMPAN) in improving the performance of the Bekasi Madya Tax Office employees shows that the obstacle in implementing the SIMPAN application is the transfer application maker to another office so that if there is a problem with the SIMPAN application it cannot be resolved immediately, the data has not been uploaded so that sometimes the latest archive is not found. The use of an application will not be separated from internal and external obstacles.

3. From interviews with internal informants from the Bekasi Madya Tax Office as primary data that is displayed in coding Verbatim analysis of efforts to overcome the barriers to the Archives Management System Application (SIMPAN) in improving the performance of the Bekasi Intermediate Tax Office employees shows that the Bekasi Intermediate Tax Office has appointed an employee who understands the ins and outs of the SIMPAN application as a PIC regarding the use of this application and appoints an employee with a level above the employee as a supervisor as well as the person in charge to ensure that scanning documents/files are always uploaded so that data is always updated. For the application to be useful in completing the work, the employee must master the application, and the application must continue to be developed and patented so that it is not recognized by irresponsible parties.

\section{CONCLUSION}

Based on the description of the research results from the discussion, it can be concluded as follows: 
The Effectiveness of Using the Application of Coverage Management System (SIMPAN) at the Madya Tax Office Bekasi, West Java, Indonesia

Rulandari, Haryati, Kommer, Agustina, Prihandini

1. The use of the SIMPAN application at the Bekasi Madya Tax Office has been effective in improving employee performance because it makes it easier, shortens time, reduces the risk of human error, better records management, and the data presented is very accurate and relevant.

2. Obstacles in implementing the SIMPAN Application at the Bekasi Madya Tax Office, namely:

a. Appoint an employee as a PIC and a supervisor related to the SIMPAN application to solve problems that occur in the application, form a helpdesk to overcome application errors and compile and publish a guidebook for the implementation of the SIMPAN application.

The maker of the SIMPAN application has transferred to another office, so there are problems if there are errors in the application.

b. Sometimes the latest archive is not found, because the file has not been uploaded.

3. The efforts made by KPP Madya Bekasi are:

a. One employee has been appointed as the PIC related to the SIMPAN application, when there are problems related to the SIMPAN application, the employee will contact and ask the solution maker for the SIMPAN application.

b. An employee has been appointed as the person in charge of the SIMPAN application to ensure that scanning documents/files are always uploaded to the SIMPAN application so that the data is always updated.

\section{REFERENCE}

Aditya, G. N. I. A. (2021). Perhitungan Kebijakan Insentif Pajak Penghasilan di Masa Pandemi Covid-19. Eqien: Jurnal Ekonomi Dan Bisnis, 8(2), 155-162. https://doi.org/10.34308/eqien.v8i2.247

Anggraini, D., Damayanti, \& Nurmala. (2021). Strategi Pengembangan Bisnis dengan Pemanfaatan Insentif Pajak dan Digitalisasi UMKM di Era New Normal. Jurnal Kajian Agribisnis Dwijen Agro, 11(1), 24-32.

http://ejournal.undwi.ac.id/index.php/dwijenagro/article/view/1081

Bai, C., Quayson, M., \& Sarkis, J. (2021). COVID-19 pandemic digitization lessonPenerapan Digitalisasi Administrasi Perpajakan dalam Upaya Mengoptimalkan Penerimaan Pajak di Tiga KPPs for sustainable development of micro-and small- enterprises. Sustainable Production and Consumption, 27, 1989-2001. https://doi.org/10.1016/j.spc.2021.04.035

Bungin, B. (2017). Metodologi Penelitian Kualitatif(B. Bungin (ed.); 3rd ed.). RajaGrafindo Persada. https://www.rajagrafindo.co.id/produk/metodologi-penelitian-kualitatif-burhan-bungin/

Chen, L., Li, Q., Zhao, X., Fang, Z., Peng, F., \& Wang, J. (2019). Multi-population coevolutionary dynamic multi-objective particle swarm optimization algorithm for power control based on improved crowding distance archive management in CRNs. Computer Communications, 145, 146-160. https://doi.org/10.1016/j.comcom.2019.06.009

Creswell, J. W. (2017). Research Design Pendekatan Kualitatif, Kuantitatif, dan Mixed (S. Z. Qudsy (ed.); 3rd ed.). Pustaka Pelajar. https://opac.perpusnas.go.id/DetailOpac.aspx?id=1213690

Diani, N. R. (2017). Efektivitas Penerapan Sistem Informasi Manajemen Kepegawaian (SIMPEG) Pada Badan Kepegawaian dan Diklat Daerah (BKDD) Kabupaten Enrekang [Universitas Hasanudin]. 
The Effectiveness of Using the Application of Coverage Management System (SIMPAN) at the Madya Tax Office Bekasi, West Java, Indonesia

Rulandari, Haryati, Kommer, Agustina, Prihandini

https://pdfcoffee.com/skripsi-nur-rahma-diani-ok-pdf-free.html

Febria, P. D., Yunus, Y., \& Putri, N. E. (2018). Efektivitas Penerapan Aplikasi Sistem Informasi Manajemen Daerah (SIMDA) Keuangan di Kantor Sekretariat DPRD Kabupaten Tanah Datar. Repository Universitas Negeri Padang, 1(1), 131-142. http://jmiap.ppj.unp.ac.id/index.php/jmiap/article/download/10/9/

Górska, A., Dobija, D., Grossi, G., \& Staniszewska, Z. (2021). Getting through COVID-19 together: Understanding local governments' social media communication. Cities, 103453. https://doi.org/10.1016/j.cities.2021.103453

Hajawiyah, A., Suryarini, T., Kiswanto, \& Tarmudji, T. (2021). Analysis of a tax amnesty's effectiveness in Indonesia. Journal of International Accounting, Auditing and Taxation, 44, 100415. https://doi.org/10.1016/j.intaccaudtax.2021.100415

Harjo, D. (2019). Perpajakan Indonesia : Sebagai Materi Perkuliahan di Perguruan Tinggi (2nd ed.). Mitra Wacana Media. https://openlibrary.telkomuniversity.ac.id/pustaka/30491/perpajakanindonesia-sebagai-materi-perkuliahan-di-perguruan-tinggi.html

Haryanto. (2020). Dampak COVID-19 terhadap Pergerakan Nilai Tukar Rupiah dan Indeks Harga Saham Gabungan (IHSG). The Indonesian Journal of Development Planning, 4(2), 151-165. https://doi.org/https://doi.org/10.36574/jpp.v4i2.114

Hertiwi, H. (2020). Penerapan Sistem Informasi Manajemen Untuk Peningkatan Produktivitas Kerja Pada Dinas Komunikasi dan Informatika (Diskominfo) Kabupaten Lombok Utara [Universitas Muhammadiyah Mataram]. In Repository UMMAT (Vol. 9, Issue 1). https://repository.ummat.ac.id/1294/

Irkham, A., Rahardian, F., Ismail, G. M., Jumadi, Desyani, T., Endar, \& Nirmala. (2021). Analisa dan Perancangan Aplikasi Kearsipan (E-Arsip) Menggunakan UML. Jurnal Teknologi Sistem Informasi Dan Aplikasi, 4(3), 145-150. https://doi.org/10.32493/jtsi.v4i3.10787

Kementerian Keuangan. (2021). Informasi APBN 2021: Percepatan Pemulihan Ekonomi dan Penguatan Reformasi. https://www.kemenkeu.go.id/media/16835/informasi-apbn-2021.pdf

Latofah, N., \& Harjo, D. (2020). Analisis Tax Awareness Dalam Upaya Meningkatkan Kepatuhan Wajib Pajak Di Kantor Pelayanan Pajak Pratama Bekasi Barat. Jurnal Pajak Vokasi (JUPASI), 2(1), 52-62. https://doi.org/10.31334/jupasi.v2i1.1121

Mapoma, M. (2017). Effective use of information technology for performance management in Zambian government institutions. World Scientific News, 61(1), 1-51. http://www.worldscientificnews.com/wp-content/uploads/2016/11/WSN-611-2017-151.pdf

Mardiasmo. (2016). Perpajakan (Mardiasmo (ed.); 3rd ed.). Andi Publishing. http:/ /www.library.usd.ac.id/web/index.php?pilih=search\&p=1\&q=0000133697\&go=Det ail

Masdi, A. (2021). Menakar Penerimaan Pajak di Tabun Pandemi. Artikel \& Opini Kementerian Keuangan. https://www.kemenkeu.go.id/publikasi/artikel-dan-opini/menakarpenerimaan-pajak-di-tahun-pandemi/

Muhyiddin, M., \& Nugroho, H. (2020). Covid-19, New Normal, dan Perencanaan Pembangunan di Indonesia. Jurnal Perencanaan Pembangunan: The Indonesian Journal of Development Planning, 4(2), 240-252. https://doi.org/10.36574/jpp.v4i2.118 
The Effectiveness of Using the Application of Coverage Management System (SIMPAN) at the Madya Tax Office Bekasi, West Java, Indonesia

Rulandari, Haryati, Kommer, Agustina, Prihandini

Pendit, I. P. W. L., Budiartha, I. N. P., \& Widiati, I. A. P. (2021). Kebijakan Pemerintah dalam Memberikan Insentif Pajak Penghasilan Pasal 21 Kepada Wajib Pajak Terdampak Pandemi Covid-19. Jurnal Konstruksi Hukum, 2(2), 418-423. https://doi.org/10.22225/jkh.2.2.3266.418-423

Rahmah, N. A. (2020). The Impact of Covid-19 on Micro, Small, Medium Enterprises (UMKM) In Indonesia. Universitas Islam Negeri Antasari. https://www.academia.edu/42694142/Karya_Tulis_Ilmiah_Nadia_Amalia_Rahmah

Shabrina, K. N. (2014). Efektivitas Pengamanan Aset dalam Mewujudkan Akuntabilitas di Pemerintah Kota Surabaya. Jurnal Kebijakan Dan Administrasi Publik, 2(1), 1-9. http://journal.unair.ac.id/download-fullpapers-kmpf88971bddcfull.pdf

Shalihah, N. F. (2020, September 15). Melihat Kasus Harian Covid-19 Indonesia Dibanding Negara Lain di Dunia. Kompas.Com, 3.

https://www.kompas.com/tren/read/2020/09/15/142400465/melihat-kasus-hariancovid-19-indonesia-dibanding-negara-lain-di-dunia?page $=$ all

Sugiyono. (2019). Metode Penelitian Kuantitatif Kualitatif dan R\&D (I). Alfabeta. https://cvalfabeta.com/product/metode-penelitian-kuantitatif-kualitatif-dan-rd-mpkk/

Syafitri, Y. (2018). Penerapan Digitalisasi Administrasi Perpajakan dalam Upaya Mengoptimalkan Penerimaan Pajak di Tiga KPP [Universitas Parahyangan]. In UNP AR Institutional Repository. http://hdl.handle.net/123456789/7064

Tray, E., Leadbetter, A., Meaney, W., Conway, A., Kelly, C., Maoiléidigh, N. Ó., de Eyto, E., Moran, S., \& Brophy, D. (2020). An open-source database model and collections management system for fish scale and otolith archives. Ecological Informatics, 59, 101115. https://doi.org/10.1016/j.ecoinf.2020.101115

UNICEF. (2021). Analysis of the Social and Economic Impacts on COVID-19 and Strategic Policy Recommendations for Indonesia. https://t.ly/jugN

Wiryawan, I. W. (2020). Kebijakan Pemerintah Dalam Penanganan Pandemi Virus Corona Disease 2019 (Covid-19) di Indonesia. Percepatan Penanganan COVID-19 Berbasis Adat Di Indonesia, 179-188. https://ejournal.unmas.ac.id/index.php/webinaradat/article/view/1180

Wulandari, D. S. (2021). Digitalisasi Sistem Administrasi Perpajakan dan Biaya Kepatuhan Pajak Terhadap Kepatuhan Wajib Pajak Orang Pribadi. Journal of Accounting Science, 5(1), 36-70. https://jas.umsida.ac.id/index.php/jas/article/view/1131 